\title{
27 \\ SMUGGLING, SURVIVAL, AND CIVIL WAR ECONOMIES
}

\author{
Aisha Ahmad
}

Civil wars create serious consequences for neighbouring states, such as mass displacement, weapons proliferation, and other deadly contagion effects (Lake and Rothchild, 1998; Bourne, 2005; Greenhill, 2008). One of the less obvious spillover effects of civil wars is the militarization and criminalization of economic networks in border regions. In many parts of the world, informal trading economies existed for centuries before the formation of modern state borders; however, when civil wars break out, these conflicts mutate old commercial systems into new criminal networks. In this chapter, I explain why and how civil wars alter pre-existing smuggling economies, turning the informal into the illicit.

To help the reader understand this phenomenon, I present evidence from three key countries where smuggling and civil war intersect: Afghanistan; Somalia; and Mali. An historical and political analysis of contemporary wartime smuggling economies in these three cases is essential to understanding the intersection between criminality and insurgency today. By taking seriously the effects of colonialism and Cold War interference on longstanding informal trade economies, this chapter provides needed context on both contemporary civil wars and the war economies that sustain them.

Afghanistan, Somalia, and Mali are three of the most volatile conflict zones in the world today, and each of these border regions is home to rampant smuggling and criminal activity. Drawing on over a decade of field research, my analysis reveals why these states were predisposed to crisis and collapse, resulting in the militarization and criminalization of the informal economies in their borderlands. My empirical observations presented in this chapter draw from the scholarly literature, as well as my own qualitative and quantitative data collected in each of these regions. My field research, conducted as part of larger global projects on civil war economies, was conducted in compliance with strict university research ethics protocols.

The chapter unfolds in the following four parts. In the first section below, I outline the historical and political origins of smuggling, specifically looking at how colonial borders affected existing economic systems in each of these three countries. Second, I show how international interference helped catalyze the eruption of civil war in Afghanistan, Somalia, and Mali. Third, I critically examine the concept of legality in contemporary civil wars, and then outline some of the features of smuggling in civil wars. In the fourth and final part, I conclude with some observations on smuggling and human survival. 


\section{Old trade routes and modern borders}

In order to analyze smuggling operations in contemporary civil wars, it is first necessary to unpack the historical origins of these economic networks. Much of the existing literature on civil war economies focuses on how resources can fuel conflict processes (Collier and Hoeffler, 2004; Le Billion, 2006). Scholars such as Ross (2004), Fearon (2004), and Lujala et al. (2005) investigated the relationship between natural resources and civil war onset or duration, and found that having large mineral endowments can worsen conflict in low- and middle-income countries. Building on this core "resource curse" literature, other scholars have investigated how oil or aid resources also may produce similar consequences on conflict duration and severity (Shearer, 2000; Ross, 2006; Cotet and Tsui, 2013).

More recent developments in the civil war economy literature have focused more closely on how rebel groups finance their operations. Specifically, the "rebel governance" literature draws on insights from the resource curse scholarship, but focuses on why insurgent groups often tax and govern communities, much like states do (Hoffmann, Vlassenroot and Marchais, 2016). For example, Weinstein (2007) shows that rebels with natural resource endowments engage in more predatory violence, but insurgents who rely on taxes to stay afloat are more likely to curtail their violence and develop governance relationships with citizens. Building on these insights, Mampilly (2011) draws on years of fieldwork in multiple conflict zones to explain why rebels govern in some cases more than others. Similarly, through her extensive field research in Colombia, Arjona (2016) explains how rebels seek to rule over citizens, resulting in the emergence of an unexpected type of wartime social order.

The civil war economies literature is not, however, limited to the study of natural resources or rebel taxation. A burgeoning body of scholarship has also emerged that examines the role of private businesses in conflict zones. Shelley (2014) uncovers how corruption, organized crime, and terrorism become entangled in conflict zones around the world. Ahmad (2017) explains why and how business elites played a role in jihadist takeovers in Somalia, Afghanistan, Mali, and Iraq. Much has also been written on the relationship between organized crime and terrorism, particularly on the relationships between narcotics trafficking and insurgent or terror groups (Hutchinson and O'malley, 2007; Boeke, 2016).

This chapter builds on, but also diverges from, this literature by uncovering how these economic systems have evolved and mutated over time. The transnational criminal networks that dominate civil war economies today did not materialize out of a void. Rather, these illicit economies are often modern mutations of informal trade and transit networks that existed long before the state. This historical context is essential for understanding what is referred to as smuggling today. As this volume has made clear, smuggling is the clandestine import or export of goods across an international border, which evades the payment of trade taxes and customs duties levied by the state (Forstater, 2018). When traders skirt past government taxes and regulations at a border, we call them smugglers.

Herein lies the problem. For much of the world, the modern state and its borders are a relatively new construct, spread through the violence of colonialism, and with little consideration of social and economic realities on the ground (Griffiths, 1986). When European imperialists drew these borders across Africa, Asia, and the Americas, their goal was to carve up land and steal resources from these civilizations (Rodney, 1972). These colonial lines, often drawn on a map with a ruler, haphazardly divided ancient social and economic systems into separate territories (Asiwaju, 1985).

When postcolonial states inherited these borders decades later after regaining independence, they thus became responsible for regulating movement across these foreign-drawn lines. In 
many cases, these boundaries existed on maps, but had no meaning on the ground. It is therefore unsurprising that precolonial social and economic systems often continue to play a more significant role in everyday life than the state itself (Meagher, 2005).

Nonetheless, many of these newly independent states desperately needed revenue, and therefore tried to levy import-export taxes at their borders (Bird, 2012). This move rendered informal precolonial trade networks - a primary source of income for many families - illegal (Meagher, 2014). Of course, in many cases these newly independent governments also lacked mechanisms to enforce the collection of these duties (Prichard et al., 2019). As a result, many people simply ignored these new trade taxes, and continued to move goods as they had for many hundreds of years (Boone, 2014).

The majority of these people do not see themselves as smugglers, nor do they believe their cross-border businesses are illicit or illegitimate (Reitano and Shaw, 2014). Traders and transporters in these borderlands often have centuries-old family connections along ancient trade routes, and believe in the legitimacy and appropriateness of continuing trade in their traditional ways (Bøås, 2012). Rather, it is these new borders, taxes, and regulations that often have no legitimate historical or social basis within these borderland communities.

For example, in the border region between Pakistan and Afghanistan, trade has flowed across these mountain passes for many hundreds of years before the delineation of the so-called Durand Line, drawn by British diplomat Mortimer Durand in 1893 (Omrani, 2009). Durand, who knew nothing of these ground realities, drew this line through an ancient and wellestablished social and economic community (Omrani, 2009). This line remains politically contentious to present day, and has produced a slew of devastating security crises.

From an economic standpoint, the Durand Line is also the origin point of the contemporary smuggling industry in this border region. In the 1960s, Pakistan's imposition of customs duties on trade inadvertently gave birth to a new smuggling industry that profited off the evasion of these taxes. Of course, traders circumventing these duties insisted that their business dealings were appropriate, rooted in both kinship and history. They argued that these caravan passes were part of the centuries-old Silk Route that connected China, Persia, and Rome, and that their families had transited goods through these mountain routes for generations. ${ }^{1}$ For many of these businesspeople, it was not their trade that was illegitimate; it was the border and the duties that were a sham.

The Malian-Algerian border proved equally problematic. This border was drawn by French imperialists, with a ruler, and cut through the middle of the Sahara desert (Lecocq, 2010). Once again, there was no demarcation of this border on the ground, and yet it officially divided Tuareg and Moorish communities and families in the region into separate countries (Hoehne and Feyissa, 2013). This French-drawn line also cut straight through well-established and vital trade networks that had connected the Sahelian and Saharan regions (Scheele, 2012). Tuareg and Moorish traders in this border region have moved goods and gold along these ancient caravan routes for centuries (Lydon, 2009) and continue to rely on these networks to acquire everyday essentials. The French-drawn border arbitrarily cut up these old caravan routes. When the Malian and Algerian states gained independence, the line became an international border, and so the unregulated movement of goods along these routes could now be called smuggling.

Of course, few consider their historic trade to be smuggling. In fact, Tuareg and Moorish communities in this region see their everyday commercial and transport businesses as not only legitimate, but also critical to survival. ${ }^{2}$ These communities live in remote and scarce border regions, and have received very little state support for economic development (Lecocq, 2010). In both the colonial and postcolonial periods, their relationship with the state has been distant 
and fraught (Kone, 2017). Unsurprisingly, the Malian-Algerian border region has also produced a plethora of disastrous security problems.

The same story applies to Somalia's troublesome borders. These modern borders cut through ancient economic networks that connected the Indian Ocean sea trade to the East African interior (Mubarak, 1997a; Ahmad, 2017). Decided by British, French, and Italian colonialists, these lines were once again drawn with a ruler on a map in the middle of a desert (Lewis, 1980). European avarice and competition over lucrative African territories led to the demarcation of these colonial borders in the late nineteenth century, which had serious political and economic consequences for the entire region (Thompson, 2015).

In terms of social and political impact, these lines divided ethnic Somalis into five different colonial polities: French Somaliland; British Somaliland; Italian Somaliland; British-colonized Kenya; and Italian-occupied Ethiopia. These divisions also had serious repercussions for the traditional trade networks that supported livelihoods across the region (Thompson, 2015). For many hundreds of years, Somalia's coastline has housed important seaport entrepôts connecting East Africa to important Indian and Middle Eastern maritime trade networks. French, Italian, and British colonial borders slashed through these well-established economic systems.

These borders carried forward into the postcolonial period, resulting in the formation of modern-day Djibouti, Somalia, Ethiopia, and Kenya (Lewis, 1980). Each of these newly independent countries was responsible for its own trade regulations and customs duties, and for controlling the movement of people and goods across these borders. While this technically turned informal trade into smuggling, in practice, the remote desert regions between these countries remained largely ungoverned. As such, most people living in these peripheral border areas - almost all who are Somalis - simply carried on with their business as usual (Rasmussen, 2017; Majidi, 2018). Like many other countries that inherited colonial borders, Somalia has also had violent and fraught relationships internally and with its neighbours (Bereketeab, 2013).

In each of these three cases, European colonialists created absurd borders that divided and disrupted well established social and economic systems. Ancient trading economies existed in these regions over many centuries, and had no connection to the colonial borders that were forced upon them. This historical context is essential for understanding the origins of smuggling economies, well before the outbreak of modern civil wars.

\section{The road to civil war}

Having established where each of these smuggling economies came from, it is necessary next to outline why and how civil wars erupted in the cases examined here, and how these civil wars then further mutated these economic systems, turning the informal into the illicit. This historical political analysis requires an evaluation of the consequences of both inherited colonial borders and aggressive Cold War interference. It is no surprise that the disastrous civil wars in Afghanistan, Somalia, and Mali all occurred after the Cold War. Close examination of these three cases reveals that these civil wars were the result of sustained external interference by foreign powers.

Afghanistan is arguably a quintessential case. The decade-long 1979-1989 Soviet military invasion and American-backed mujahideen rebellion left over a million people dead, and millions more injured or displaced (Edwards, 2002). The Soviets irreparably ruined much of Afghanistan's agricultural land, in an effort to starve the population into submission (Byman, 2015). Meanwhile, the United States colluded with Pakistan to traffic weapons and supplies through the smuggling channels in the mountains (Rubin, 2000). Because the Soviets had scorched orchards and farmlands across Afghanistan, farmers turned to hardy and reliable opium 
crops to stay afloat (Kreutzmann, 2007). The smuggling community in the PakistanAfghanistan border region soon found itself moving guns into Afghanistan, and drugs out (Ahmad, 2017).

When the Soviets finally withdrew in defeat, the war-ravaged country proved unable to recover from such brutal political and economic devastation (Byman, 2015). Then-President Mohammad Najibullah attempted to steward a transition between 1989 and 1992, but he had remained dependent on Soviet support to stay afloat (Cordovez and Harrison, 1995). This transitional government was also strongly opposed by the mujahideen rebels who resented Najibullah's communist and Soviet affiliations (Rubin, 2013).

The abrupt end of the Cold War catalyzed another wave of conflict. By 1992, Soviet support had dried up, and Najibullah's government went bankrupt. Between 1992 and 1996, Afghanistan descended into a civil war among the former mujahideen rebel factions, many backed by neighbouring Pakistan (Akhtar, 2008). Bodies piled in the streets and rape gangs terrorized women and children from rival ethnic and religious communities. This ethnic civil war was so brutal that it eventually led to the rise of the Taliban, and further exacerbated militarization and radicalization in the Pakistan-Afghanistan border region (Goodson, 2001).

After both the Americans and Soviets lost interest in Afghanistan following the end of the Cold War, Pakistan continued its aggressive, blatant interference via the unruly border (Akhtar, 2008). The Pakistan-Afghanistan border region remained the chief conduit of this interference, and the epicentre of both insurgency and illicit trade. The infiltration of Arab terrorist networks in Afghanistan culminated in the devastating 9/11 attacks, followed by a 20-year American-led occupation. After 40 years and repeated international interventions, Afghanistan has not recovered from this legacy of external interference and internal fragmentation.

Somalia suffered a similar fate. Although Somalia did not suffer a full-scale superpower invasion during the Cold War, it did become dangerously entangled with both the Soviets and the Americans. From 1969 until the late 1970s, dictator and then-President, Siad Barre adopted a socialist political and economic platform in order to win desperately needed foreign support from the Soviet Union (Samatar, 2016). However, Barre was also obsessed with redrawing the ruler-drawn colonial borders that divided ethnic Somalis into different countries (Mukhtar, 2003). In 1977, Barre launched a military offensive to recapture the Ogaden region of Ethiopia, and act that provoked international condemnation, including from the Soviets. This border war not only failed, but the Ogaden War also ended Somalia's relationship with the Soviet Union.

Given his dependence on foreign support, Barre was therefore forced to court an American alliance (Mukhtar, 2003). To prove his new loyalty and secure a desperately needed IMF loan, in the early 1980s Barre implemented a number of drastic economic reforms that reversed his previous socialist policies (Mubarak, 1997b; Samatar, 2008). Fearing disloyalty and opposition, he also began favouring his own clan faction and violently targeting his rivals, which only worsened economic disparity and increased clan conflict (Lewis, 2008).

The end of the Cold War sent Somalia into a tailspin. The combination of dwindling foreign support and haphazard IMF-imposed economic reforms culminated in an economic crisis. With no superpower to bail him out, the Barre government went bankrupt. Hawiye clan militias seized control of Mogadishu, and Barre's Darod-Marehan clan were butchered in the streets. The government dissolved in 1991 and Barre fled. The Somali countryside was overrun by armed groups that created their own fiefdoms, each run by a local clan warlord (Makinda, 1999). An ill-timed drought compounded the crisis; together, civil war and famine produced a devastating humanitarian disaster.

Between 1992 and 1995, the UN launched an intervention in Somalia, which aimed to protect food aid deliveries and restore political order. Instead, these aid convoys unwittingly 
helped empower the reigning Hawiye-Abgal, while marginalizing the rival Hawiye-Habr-Gidr clan (Ahmad, 2012). In response, the aid convoys were attacked, and the UN was dragged into a clan conflict it did not understand. Food aid became a wartime currency, and traditional traders grew rich by looting and trafficking these sacks of grain. After the UN withdrew in failure in 1995, Somalia descended into a brutal clan-based civil war.

In 2006, a local movement of Islamic courts overthrew the clan warlords, established a new government, and briefly restored peace and security (Barnes and Harun, 2007). By 2007, however, this Islamic government was quickly overthrown by a new US-backed Ethiopian invasion (Samatar, 2007). Not only did this external interference plummet Somalia back into a clan-based civil war, but it also gave birth to a new jihadist insurgency, al-Shabaab, that continues to control large swaths of the countryside (Ahmad, 2017). Despite countless international interventions, or perhaps because of them, Somalia has now been at war for three decades.

The Malian case was, for many years, heralded as a shining example of post-Cold War success, even after suffering years of foreign interference, brutal IMF-imposed structural adjustment policies, economic upheaval, and military dictatorship. ${ }^{3}$ Unlike Afghanistan and Somalia, Mali survived the end of the Cold War without a civil war. Despite widespread protests and a military coup in 1991, the country avoided either a return to authoritarianism or a civil war. In the 1990s, analysts were quick to hail Mali as a grand success (Storholt, 2001).

These optimistic observers did not, however, pay close attention to what was happening in the northern border region at these critical time periods. While Mali appeared to be a democratic success, severe conflict processes had already developed in the north of Mali and in Algeria, which would eventually catalyze a devastating civil war. First of all, during the Cold War, then-President Moussa Traoré had clamped down on the restive Tuareg population in northern Mali, leaving them impoverished and marginalized (Lecocq and Klute, 2013). When the Cold War ended, these repressed populations pushed back, once between 1990 and 1995, and again between 2007 and 2009 (Lecocq and Klute, 2013). While the government quelled these Tuareg revolts, these repeated uprisings revealed a systemic failure by the Malian government to control and integrate its northern border region into the country. The Frenchdrawn border between Mali and Algeria and decades of western-backed dictatorship guaranteed conflict with these northern communities.

Second, while Mali was relatively peaceful in the 1990s, neighbouring Algeria was not. ${ }^{4}$ In fact, the 1991-2002 civil war in Algeria gave birth to a jihadist movement that had serious implications for Mali. When Algerian government pushed back its jihadists, they retreated into the Saharan hinterland (Bøås, 2015). By 2002, the extremist Salafist Group for Preaching and Combat (GSPC) was the only significant jihadist group left in Algeria, and it had retreated south towards the ungoverned Malian border region. On its heels, the GSPC launched a lucrative kidnapping-for-ransom campaign (Bøås, 2015). With its ransom moneys, these Algerian jihadists then built relationships with both Tuareg rebel leaders and smugglers in the border region. By 2006, the GSPC has transformed into Al-Qaeda in the Islamic Maghreb (AQIM), and emerged as the leading terrorist group in the region, with strong links to smuggling networks in northern Mali. Therefore, while democracy in Bamako appeared politically stable, an unprecedented conflict was fomenting in the restive northern border region.

The third major catalyst of the 2012 Malian crisis came not from neighbouring Algeria, but from nearby Libya. This Libyan-Malian connection had been developing for many decades, as disenfranchised Malian Tuaregs long sought refuge and economic opportunities in oil-rich Libya. Notably, many young Tuareg men from this Malian diaspora had found jobs in Muammar Gaddafi's paramilitary Islamic Legion (Shaw, 2013). As a result, when in 2011 
NATO launched a military operation that toppled Gaddafi and plummeted Libya into a devastating civil war, the Malian Tuareg diaspora fled Libya. At this time, many Malian Tuareg who had been living in Libya returned home to northern Mali with advanced weapons and training (Marsh, 2017).

The NATO intervention therefore not only collapsed the Libyan state, but also catalyzed the civil war in Mali (Ronen, 2013; Shaw, 2013). The evidence suggests that returning diaspora fighters from Libya joined forces with Tuareg rebels and their new AQIM allies, and in 2012, launched a countrywide separatist campaign (Boeke and de Valk, 2019). Since this uprising, Mali has become one of the most dangerous and extreme conflict zones in the world today.

Each of these cases reveals an important underlying fact. Civil wars are international phenomena. Not only did these countries inherit problematic colonial borders, but foreign parties also incited and inflamed conflicts inside their already fraught borders. Afghanistan, Somalia, and Mali all collapsed under the weight of these external pressures. The causes of these domestic political crises were international, and so it is not surprising that their ramifications cross borders.

It should now be clear that the sophisticated transnational smuggling networks in contemporary conflict zones do not originate out of the ether at the moment war breaks out. Rather, these are modern mutations of longstanding informal economic systems, many of which have existed and evolved over hundreds of years, and have adapted to survive multiple external shocks. Civil wars, therefore, do not cause smuggling; rather, these conflicts further mutate longstanding informal trading networks into new militarized and criminalized borderland economies.

\section{Legality in lawless lands}

Understanding these criminal economies requires a critical analysis of what legality means in a civil war. Law is a manifestation of power. For example, European imperialists created laws that allowed them to steal from and enslave local people. These moral crimes were legal because those in power wrote the laws. Indeed, law and justice are often incongruent. Yet, in all modern states, the government is supposed to define rules and enforce compliance, and this coercive power is the cornerstone of modern political order-making. However, when the power behind that order weakens, or collapses, the law loses its hold over society. When the rule of law is absent, contested, or unenforceable, it can be difficult to determine what is legal or illegal, or whether these terms even make sense.

Of course, most contemporary conflict zones are hubs of both insurgent violence and criminal activity. When rebel groups compete for power and territory, they necessarily require resources and supplies to finance their war effort: guns; bullets; food; and medical supplies. To acquire these supplies, rebels tax, steal, pillage, divert, swindle, mine, and traffic. Much of the existing scholarship on smuggling in civil wars therefore investigates the intersections of criminality, insurgency, and terrorism (Cornell, 2005). When researchers "follow the money," they are investigating how armed groups capture diamond mines (Ross, 2006), divert humanitarian aid (Ahmad, 2012), traffic drugs (Björnehed, 2004), or extort civilians (SabatesWheeler and Verwimp, 2014). In order to make sense of these civil war economies, however, it is necessary to reflect critically on the concept of legality.

In each of the three cases in this chapter, state weakness and failure produced legal grey zones in the borderlands. For the smuggler in northern Kidal, the Malian government sitting in southern Bamako has no right to interfere with his longstanding trade relations. The businessman in Spin Boldak has little time for economic policy debates in either Kabul or 


\section{Aisha Ahmad}

Islamabad. The trader in Gedo region is not interested in tariffs and regulations that benefit Somali politicians sitting in Mogadishu. These cases reveal a disparity between what governments declares to be law, and what communities consider to be appropriate.

The outbreak of civil war is an intensification of this disparity. Rebellions usually happen when communities hit a breaking point, turning tensions into violence (Keen, 2000). It is often a justice motive that sparks rebels to take up arm against the government, based on a perceived disparity between benefits and entitlements (Gurr, 1970; Welch, 1993). When rebels challenge the state for the right to rule, not only is there no longer a monopoly on the use of force, there is also an active competition over the system itself. Regardless of which side is officially recognized by the international community, a civil war is evidence of a violent domestic disagreement about who has the right to rule.

This does not mean that the rebel challenger needs to articulate or codify an alternative set of laws. The act of violently contesting power inherently implies a challenge to the rules and regulations of the state. When rebels seize control of territory from the state, they may declare certain contraband goods legal, or government taxes forfeit. They may also impose new taxes and regulations of their own (Mampilly, 2011; Sabates-Wheeler and Verwimp, 2014; Arjona, Kasfir and Mampilly, 2015; Arjona, 2016; Revkin, 2020). Communities that are caught between government and rebel actors in this military contest are often forced to accept whatever version of law is imposed on them.

Of course, it is more likely that rebellions will emerge in regions where the government already has less influence and where its ability to enforce its laws is already weak (Herbst, 2001). Peripheral regions and borderlands that are located far from government centres of control are often more vulnerable, especially if there are pre-existing grievances that insurgents can coopt. As rebel challengers assume control over these territories, they necessarily build new relationships with the informal economic communities in these borderlands, whether through incentives or coercion (Malik and Gallien, 2020).

For the informal traders who have long operated in these borderlands, the outbreak of civil war presents a slew of new challenges and opportunities. There are new forms of rebel extortion and taxation, as well as dramatic shocks to supply and demand in local and regional markets. However, civil wars also often attract new connections to transnational criminal organizations, and greater opportunities in illicit trade (May 2017; Adetiba, 2019).

To start, it is common for cash-strapped rebels to shake down businesses for "taxes," so that they can finance their war effort. For smugglers who have made a living off of tax-free trade, rebel taxes can eliminate their competitive edge. Even more, when there are multiple, competing armed groups operating in a border region, a businessperson can get taxed by each faction along a trade route. These compound rebel taxes dramatically increase the price of goods at point of sale, and can have a crushing effect on an entire smuggling industry (Ahmad, 2017).

Civil wars do not, however, produce only debits. In many cases, rebels also create new opportunities for businesses, especially in illicit trade. Not only can armed groups provide protection for traffickers operating in active conflict zones, but they often also bring forward new investments and connections that can expand business opportunities. As noted earlier, AQIM earned tens of millions of dollars in kidnapping for ransom, which then allowed it to invest in revamping the smuggling industry in the Malian-Algerian border region (Bøås, 2015). Within a few years, the traditional smuggling community in northern Mali had mutated into the hub of the cigarette trafficking across West Africa (Raineri and Strazzari, 2015). This success then drew the attention of even bigger transnational criminal organizations. With AQIM and other armed groups providing cover, the Malian-Algerian border region became a conduit for cocaine trafficking, connecting Latin American drug cartels to European markets (Ellis, 2009). 
Of course, it is not only rebels who become entangled in criminal activity. With such lucrative opportunities available, many political actors on the side of the state also become heavily involved in organized crime. In Mali, for example, the leader of the pro-Government Groupe autodéfense touareg Imghad et alliés (GATIA) has been heavily implicated in narcotics trafficking (International Crisis Group, 2018). In Afghanistan, former President Hamid Karzai's brother was known for running a massive heroin operation in Kandahar (Risen, 2008). State officials in Guinea Bissau are allegedly heavily involved in narcotics trafficking, allowing Latin American drug cartels to move product into West Africa an onwards to European markets (BBC News, 2020).

State officials can also get incredibly rich through a plethora of other corrupt activities, such as looting state coffers and pilfering international aid. Tens of millions of dollars simply went missing in Karzai's government (Epstein, 2011; Rosenberg, 2013; Press, 2019). In Somalia, parliamentary positions were often treated as opportunities to loot foreign aid. ${ }^{5}$ When the rule of law functionally has collapsed, it is often players that have access to the halls of power that are the most heavily engaged in criminality and corruption.

When civil war breaks out, state actors, transnational criminal organizations, rebel groups, terrorists, and ordinary citizens all become embroiled in these complex conflict economies (L. Shelley, 2014; Ahmad, 2015). Despite fighting each other on the battlefield, sometimes these actors even make business deals across enemy lines. In Mali, for example, there is evidence that bitterly opposed ethnic factions have forged secret "gentlemen's agreements" to ensure their respective trafficking routes are not disrupted as they go to war against each other. ${ }^{6}$ As Andreas (2008) shows, even international peacekeeping forces have found themselves entangled with criminal organizations and predatory militias, even as they try to curtail these pernicious actors on the battlefield (Andreas 2008).

Civil wars not only involve a diverse set of competing actors, but also a messy mix of licit and illicit activities. Not all of the business activities in a civil war economy are dangerous or criminal. People living in a conflict zone still need to buy onions, shoes, gasoline, and cell phone chargers. A trucker may transport sugar and flour on one route, and cocaine and assault rifles on another. Rebels may illegally acquire weapons from states or private suppliers, but then may barter these arms in the marketplace to buy other essential supplies, like blankets or medicine (Adetiba, 2019). Even seemingly obvious illicit activities, like human trafficking, often have a more complex story at ground level. For example, according to ECOWAS regulations, it would be perfectly legal for a Burkinabe citizen to travel through Niger to the Malian-Algerian border without a visa; a bus company taking migrants to this border point would have broken no laws, even though it is part of a transit route connected to human smugglers in Libya (Opanike, Aduloju and Adenipekun, 2015). Similar legal questions can arise with other types of smuggling. Some border points are unregulated, whereas others may be subject to laws that have no enforcement, or that have competing claims of authority and legitimacy.

When civil wars break out, there is a challenge to the authority of the state to create and enforce such laws. Under these conditions, it may be less useful to focus on teasing out what are legal versus illegal activities, especially in places where the rule of law functionally has collapsed. Rather, it makes more sense to examine how the shock of civil war forces local business actors to adapt to survive, including in ways that may create, empower, and enrich transnational criminal cartels. This dynamic adaptation among multiple, interdependent actors better explains the complex civil war economies we see today. 


\section{Smuggling and survival}

For most people, civil war brings poverty, loss, and terrible hardships. For savvy traders and transporters, however, war can also bring about new opportunities for wealth generation. To succeed under difficult wartime conditions, smugglers must be able to adapt quickly to new market demands, locally and regionally. They must strike deals with armed groups across multiple turfs, and buy off crooked politicians, police officers, and border control agents. After greasing these wheels, they must hire or negotiate enough muscle to secure their convoys from bandits and other rivals on the roads. Finally, they must push their product and ensure their buyers can and will pay.

The financial rewards of this hustle can be lavish (Ahmad, 2017). Smugglers who demonstrate competence and success in navigating goods through a conflict zone can crush their competition, and quickly grow into wartime tycoons. With their trafficking windfalls, they form monopolies, invest in new business ventures, and build multi-company conglomerates. These powerful mafias are then able to use their economic might to influence conflict dynamics on the ground. They not only forge agreements with armed groups, but also with corrupt government actors on the take.

These business elites also play a critical role in the lives of the ordinary people living in wartime conditions: the truckers, wholesalers, merchants, shopkeepers, and even tea-sellers on the streets. Together, these diverse characters co-create the business ecosystem of the civil war economy, one that is truly interdependent. While relationships among business tycoons, rebel groups, and ordinary citizens are unequal, there is also an overall symbiosis in this business ecosystem that keep goods and cash moving.

Consider, for example, a smuggling tycoon who makes a deal with a rebel coalition to move his product, allowing each rebel faction in the alliance to take a cut in exchange for their "security." With these funds, the commanders pay their foot soldiers, who then buy liquor from their local shopkeeper. The smuggler also pays off a local government official, who distributes a cut to his cronies to ensure their loyalty. These cronies then refurbish their old jeeps at their local garage. When the smuggler finally delivers his convoy and receives his windfall, he refurbishes his home, creating new jobs and construction contracts. Of course, there is coercion and theft throughout this system. There are also everyday business activities that keep the money supply moving. When the tycoon earns and spends, the contractor, liquor store owner, driver, bricklayer, mechanic, shoemaker, and tea-seller all go home with a little extra in their pockets.

If this smuggling tycoon and the armed groups disappeared today, the cash flow would freeze and those people who are dependent on this illicit business ecosystem would go hungry. Nonetheless, narcotics, human, and weapons trafficking have a devastating effect on local and regional security, and these businesses worsen violence and human rights abuses against civilians. From both a moral and security standpoint, this unhealthy economic activity needs to stop. Indeed, the vast majority of people living in these war zones would heartily agree. In fact, even most ordinary traders and transporters who are caught up in these dangerous businesses want to transition to a safer, licit option, if another profitable opportunity was made available. ${ }^{7}$ The challenge then becomes supporting safe and sustainable alternative livelihoods for people living in these troubled borderlands.

It would be erroneous, however, to frame the economies of war-torn border regions solely in terms of criminality and corruption. Transnational criminal organizations and trafficking tycoons are not the only businesspeople in these civil war economies. Ordinary people living under wartime conditions also hustle to protect their lives and livelihoods. They respond to 
fluctuations in supply and demand, adapt to changing battlefield conditions, and build unexpected alliances to advance their security and prosperity. Even under extraordinarily challenging circumstances, human beings continue to truck, barter, and trade, in a demonstration of human resilience.

This local economic adaptation is also often a response to serious environmental and climate pressures. In each of the three cases outlined in this chapter, threats to agricultural land forced local economies to adapt (Raleigh, 2010; Ogallo et al., 2018; Privara and Privarova, 2019). During the nineteenth century, the British deforested swaths of the Pakistan-Afghanistan border region (Tucker, 1983), causing lasting desertification and soil salinization (Faiza et al., 2017). Climate change now compounds the damage caused by this historic British theft and destruction. Somalia and Mali also suffered colonial theft, and are now both located in deadly climate change red zones. Both of these countries are experiencing rapidly increasing droughts and losses of arable lands (Doucet, 2019). These environmental pressures, caused almost entirely by wealthy foreign powers, have pushed already fragile ecosystems to the brink of collapse. Naturally, human beings living in these regions must adapt their economic activities to adjust to this barrage of externally imposed political, economic, and environmental shocks.

Given this fragility, it would therefore be disastrous for the international community simply to attack wartime business ecosystems that are currently sustaining vulnerable communities. Rather, human beings in these troubled regions need economic and environmental alternatives. This is not a security problem that can be solved with force. The solutions to these problems lie in sustained investment, climate change adaptation, and new seed technologies. Most people living under these difficult conditions would welcome the development of safe and stable economic options.

Finally, it is easy to label drug smugglers and arms traffickers in unruly border regions as nefarious criminals. Yes, these are serious economic and security problems. Nonetheless, this use of language has consequences. It allows decision-makers to call the rich cocaine-sniffing European partygoer a victim, while labeling the 15-year-old Malian truck driver a villain worthy of an air strike. It labels Somali and Afghan shopkeepers arms trafficker, while ignoring the fact that the weapons they are selling were surreptitiously brought into their countries by America, Russia, and other great powers. Indeed, it requires an audacious level of intellectual and moral dishonesty to wax poetic about illegality in fragile border regions, while ignoring the sheer magnitude of colonial theft and illegal interventions these countries have suffered. Any honest conversation about these serious security and economic issues must therefore include a frank discussion about reparations.

\section{Notes}

1 Author fieldwork and interviews with traders in Pakistan-Afghanistan border region.

2 Author fieldwork, Mali. See also Bensassi et al. (2016).

3 Political leadership played a role in Mali's transition. In March 1991, the military coup led by Amadou Toumani Toure deposed Traoré. Yet, instead of claiming power for himself, Toure set up a transitional council to usher in a new democratic government. Toure stepped down from power, and in 1991 Alpha Oumar Konaré became Mali’s first democratically elected President.

4 The Algerian Civil War began when the ruling National Liberation Front (FLN) party realized it was set to lose the first-ever Algerian election to the popular Islamist Salvation Front (FIS). The FLN cancelled the election and banned the FIS, sparking a new Islamist rebellion.

5 Author's fieldwork, Nairobi, February 2013.

6 Author's fieldwork, Bamako, February 2018.

7 Interviews with arms smugglers in Afghanistan and Somalia. 


\section{Works cited}

Adetiba, T. (2019) 'Transnational syndicates and cross-border transfer of small arms and light weapons in West Africa: A threat to regional security', Journal of African Union Studies, 8(1), pp. 93-112.

Ahmad, A. (2012) 'Agenda for peace or budget for war? Evaluating the economic impact of international intervention in Somalia', International Journal, 67(2), pp. 313-331.

Ahmad, A. (2015) 'The security bazaar: Business interests and Islamist power in Civil War Somalia', International Security, 39(3), pp. 89-117. doi: 10.1162/ISEC_a_00187.

Ahmad, A. (2017) Jihad and Co. Black Markets and Islamist Power. New York: Oxford University Press.

Akhtar, N. (2008) 'Pakistan, Afghanistan, and the Taliban', International Journal on World Peace, 25(4), pp. $49-73$.

Andreas, P. (2008) Blue Helmets and Black Markets: The Business of Survival in the Siege of Sarajevo. New York: Cornell University Press.

Arjona, A. (2016) Rebelocracy. New York: Cambridge University Press.

Arjona, A., Kasfir, N. and Mampilly, Z. (2015) Rebel Governance in Civil War. New York: Cambridge University Press.

Asiwaju, A. (1985) Partitioned Africans: Ethnic Relations Across Africa's International Boundaries, 1884-1984. London: Hurst.

Barnes, C. and Harun, H. (2007) 'The Rise and Fall of Mogadishu's Islamic Courts Union', Journal of Eastern African Studies, 1(2), pp. 151-160.

BBC News (2020) 'Cocaine and Guinea-Bissau: How Africa's "narco-state" is trying to kick its habit', 28 May. Available at: https://www.bbc.com/news/world-africa-52569130 (Accessed: 22 February 2021).

Bensassi, S. et al. (2016) 'Algeria-Mali trade: The normality of informality', Middle East Development Journal, 8(2), pp. 161-183.

Bereketeab, R. (ed.) (2013) The Horn of Africa: Intra-State and Inter-State Conflicts and Security. London: Uppsala, Sweden: Pluto Press; In cooperation with Nordiska Afrikainstitutet.

Bird, R. (2012) Taxation and Development: What Have We Learned from Fifty Years of Research? Working Paper 1. International Centre for Tax and Development.

Björnehed, E. (2004) 'Narco-terrorism: The merger of the war on drugs and the war on terror', Global Crime, 6(3/4), pp. 305-324. doi: 10.1080/17440570500273440.

Bøås, M. (2012) 'Castles in the sand: Informal networks and power brokers in the northern Mali periphery', in Utas M. (ed.) African Conflicts and Informal Power: Big Men and Networks. New York: Zed Books, pp. 119-136.

Bøås, M. (2015) 'Crime, coping, and resistance in the Mali-Sahel periphery', African Security, 8(4), pp. 299-319. doi: 10.1080/19392206.2015.1100506.

Boeke, S. (2016) 'Al Qaeda in the Islamic Maghreb: Terrorism, insurgency, or organized crime?', Small Wars E Insurgencies, 27(5), pp. 914-936. doi: 10.1080/09592318.2016.1208280.

Boeke, S. and de Valk, G. (2019) 'The unforeseen 2012 crisis in Mali: the diverging outcomes of risk and threat analyses', Studies in Conflict \& Terrorism. doi: 10.1080/1057610X.2019.1592356.

Boone, C. (2014) Property and Political Order in Africa. Cambridge: Cambridge University Press.

Bourne, M. (2005) 'The proliferation of small arms and light weapons', in Krahmann E. (eds) New Threats and New Actors in International Security. New York: Palgrave MacMillan, pp. 155-176.

Byman, D. (2015) Al Qaeda, the Islamic State, and the Global Jihadist Movement: What Everyone Needs to Know. New York: Oxford University Press.

Collier, P. and Hoeffler, A. (2004) 'Greed and grievance in civil war', Oxford Economic Papers, 56(4), pp. 563-595.

Cordovez, D. and Harrison, S. (1995) Out of Afghanistan: The Inside Story of the Soviet Withdrawal. Oxford: Oxford University Press.

Cornell, S. E. (2005) 'The interaction of narcotics and conflict', Journal of Peace Research, 42(6), pp. 751-760. doi: 10.1177/0022343305057895.

Cotet, A. M. and Tsui, K. K. (2013) 'Oil and conflict: what does the cross country evidence really show?', American Economic Journal: Macroeconomics, 5(1), pp. 49-80.

Doucet, L. (2019) The Battle on the Frontline of Climate Change in Mali. BBC. Available at: https:// www.bbc.com/news/the-reporters-46921487.

Edwards, D. B. (2002) Before Taliban: Genealogies of the Afghan Jihad. Berkeley: University of California Press. Available at: http://link.library.utoronto.ca/eir/EIRdetail.cfm?Resources_ID $=39059 \& T=F$ (Accessed: 26 June 2016). 
Ellis, S. (2009) 'West Africa's international drug trade', African Affairs, 108(431), pp. 171-196.

Epstein, J. (2011) Audit: Karzai Blocking Cash Oversight. Politico. Available at: https://www.politico.com/ story/2011/07/audit-karzai-blocking-cash-oversight-059453.

Faiza, N. et al. (2017) 'Giant deforestation leads to drastic eco-environmental devastating effects since 2000: A case study of Pakistan', The Journal of Animal \& Plant Sciences, 27(4), pp. 1366-1376.

Fearon, J. D. (2004) 'Why do some civil wars last so much longer than others?' Journal of Peace Research, 41, pp. 275-301. doi: 10.1177/0022343304043770.

Forstater, M. (2018) Illicit financial flows, trade misinvoicing, and multinational tax avoidance: The same or different? CGD Policy Paper 123. Center for Global Development.

Goodson, L. P. (2001) Afghanistan's Endless War: State Failure, Regional Politics, and the Rise of the Taliban. Seattle: University of Washington Press.

Greenhill, K. (2008) 'Strategic engineered migration as a weapon of war', Civil Wars, 10(1), pp. 6-21.

Griffiths, I. (1986) 'The scramble for Africa: Inherited political boundaries', The Geographical Journal, 152(2), pp. 204-216.

Gurr, T. R. (1970) Why Men Rebel. Princeton: Princeton University Press.

Herbst, J. (2001) States and Power in Africa: Comparative Lessons in Authority and Control. Princeton: Princeton University Press.

Hoehne, M. V. and Feyissa, D. (2013) 'Centering borders and borderlands: The evidence from Africa', in Korf, B. and Raeymaekers, T. (eds) Violence on the Margins. Palgrave Macmillan US (Palgrave Series in African Borderlands Studies), pp. 55-84. doi: 10.1057/9781137333995_3.

Hoffmann, K., Vlassenroot, K. and Marchais, G. (2016) 'Taxation, stateness and armed groups: Public authority and resource extraction in Eastern Congo: Taxation and public authority in Eastern Congo', Development and Change, 47(6), pp. 1434-1456. doi: 10.1111/dech.12275.

Hutchinson, S. and O'malley, P. (2007) 'A crime-terror nexus? thinking on some of the links between terrorism and criminality', Studies in Conflict \& Terrorism, 30(12), pp. 1095-1107. doi: 10.1080/105761 00701670870.

International Crisis Group (2018) Drug trafficking, violence, and politics in Northern Mali. Africa No. 267. International Crisis Group.

Keen, D. (2000) 'Incentives and disincentives for violence', in M. Berdal and D. M. Malone (eds) Greed and Grievance: Economic Agendas in Civil Wars. Boulder, CO: Lynne Rienner, pp. 19-43.

Kone, K. (2017) 'A southern view on the Tuareg rebellions in Mali', African Studies Review, 60(1), pp. 53-75.

Kreutzmann, H. (2007) 'Afghanistan and the opium world market: Poppy production and trade', Iranian Studies, 40(5), pp. 605-621. doi: 10.1080/00210860701667688.

Lake, D. A. and Rothchild, D. S. (eds) (1998) The International Spread of Ethnic Conflict: Fear, Diffusion, and Escalation. Princeton, NJ: Princeton University Press.

Le Billion, P. (2006) Fuelling War: Natural Resources and Armed Conflict. New York: Routledge.

Lecocq, B. (2010) Disputed Desert: Decolonisation, Competing Nationalisms and Tuareg Rebellions in Northern Mali. Leiden, The Netherlands: Koninklijke Brill.

Lecocq, B. and Klute, G. (2013) 'Tuareg separatism in Mali', International Journal: Canada's Journal of Global Policy Analysis, 68(3), pp. 424-434. doi: 10.1177/0020702013505431.

Lewis, I. M. (1980) A Modern History of Somalia: Nation and State in the Horn of Africa. London: Longman.

Lewis, I. M. (2008) Understanding Somalia and Somaliland: Culture, History, Society. London: Hurst \& Co.

Lujala, P., Gleditsch, N. P. and Gilmore, E. (2005) 'A diamond curse?', Journal of Conflict Resolution, 49, pp. 538-562. doi: 10.1177/0022002705277548.

Lydon, G. (2009) On Trans-Saharan Trails: Islamic Law, Trade Networks, and Cross-cultural Exchange in Nineteenth-Century Western Africa. Cambridge: Cambridge University Press.

Majidi, N. (2018) 'Community dimensions of smuggling: The case of Afghanistan and Somalia', The ANNALS of the American Academy of Political and Social Science, 676(1), pp. 97-113.

Makinda, S. M. (1999) 'Clan conflict and factionalism in Somalia', in Rich P. B. (ed.) Warlords in International Relations. London: Palgrave MacMillan, pp. 120-139.

Malik, A. and Gallien, M. (2020) 'Border economies of the Middle East: Why do they matter for political economy?', Review of International Political Economy, 27(3), pp. 732-762.

Mampilly, Z. (2011) Rebel Rulers: Insurgent Governance and Civilian Life During War. New York: Cornell University Press.

Marsh, N. (2017) 'Brothers came back with weapons: The effects of arms proliferation from Libya', PRISM, 6(4), pp. 78-97. 


\section{Aisha Ahmad}

May, C. (2017) Transnational Crime and the Developing World. Washington, DC: Global Financial Integrity.

Meagher, K. (2005) 'Social capital or analytical liability? Social networks and African informal economies', Global Networks, 5(3).

Meagher, K. (2014) 'Smuggling ideologies: From criminalization to hybrid governance in African clandestine economies', African Affairs, 113(453), pp. 497-517.

Mubarak, J. A. (1997a) 'The "hidden hand" behind the resilience of the stateless economy of Somalia', World Development, 25(12), pp. 2027-2041.

Mubarak, J. A. (1997b) 'The "hidden hand" behind the resilience of the stateless economy of Somalia', World Development, 25(12), pp. 2027-2041.

Mukhtar, M. H. (2003) Historical Dictionary of Somalia. Oxford: Scarecrow Press.

Ogallo, L. et al. (2018) 'Climate change projections and the associated potential impacts for Somalia', American Journal of Climate Change, 7(2).

Omrani, B. (2009) 'The Durand Line: History and problems of the Afghan-Pakistan border', Asian Affairs, 40(2), pp. 177-195. doi: 10.1080/03068370902871508.

Opanike, A., Aduloju, A. and Adenipekun, L. (2015) 'COWAS protocol on free movement and trans-border security in West Africa', Covenant University Journal of Politics and International Affairs, 3(1). doi: 10.41 72/2169-0170.1000154 A

Press, K. G., The Associated (2019) Afghanistan's Karzai says American cash fed corruption, Military Times. Available at: https://www.militarytimes.com/flashpoints/2019/12/11/afghanistans-karzai-saysamerican-cash-fed-corruption/ (Accessed: 22 February 2021).

Prichard, W. et al. (2019) Innovations in tax compliance: Conceptual framework (Enforcement, Facilitation, and Trust). Policy Research Working Paper WPS9032. Washington: The World Bank.

Privara, A. and Privarova, M. (2019) 'Nexus between climate change, displacement, and conflict: Afghanistan Case', Sustainability, 11(20).

Raineri, L. and Strazzari, F. (2015) 'State, secession, and Jihad: the micropolitical economy of conflict in Northern Mali', African Security, 8(4), pp. 249-271.

Raleigh, C. (2010) 'Political marginalization, climate change, and conflict in African Sahel states', International Studies Review, 12(1), pp. 69-86.

Rasmussen, J. (2017) Sweet secrets: Sugar smuggling and state formation in the Kenya-Somalia borderlands. DIIS Working Paper 2017: 11. Danish Institute for International Studies.

Reitano, T. and Shaw, M. (2014) 'People's perspectives of organised crime in West Africa and the Sahel', Institute for Security Studies Papers, 2014(254).

Revkin, M. R. (2020) 'What explains taxation by resource-rich rebels? Evidence from the Islamic State in Syria', Journal of Politics, 82(2), pp.757-764.

Risen, J. (2008) Reports link Karzai's brother to Afghanistan heroin trade. New York Times. Available at: https://www.nytimes.com/2008/10/05/world/asia/05afghan.html.

Rodney, W. (1972) How Europe Underdeveloped Africa. Washington, DC: Howard University Press.

Ronen, Y. (2013) 'Libya, the Tuareg and Mali on the eve of the "Arab Spring" and in its aftermath: An anatomy of changed relations', The Journal of North African Studies, 18(4), pp. 544-559.

Rosenberg, M. (2013) 'With bags of cash, C.I.A. seeks influence in Afghanistan', The New York Times, 28 April. Available at: https://www.nytimes.com/2013/04/29/world/asia/cia-delivers-cash-to-afghanleaders-office.html (Accessed: 22 February 2021).

Ross, Michael L. (2004) 'What do we know about natural resources and civil war?' Journal of Peace Research, 41, pp. 337-356. doi: 10.1177/0022343304043773.

Ross, M. (2006) 'A closer look at oil, diamonds, and civil war', Annual Review of Political Science, 9, pp. $265-300$.

Rubin, B. R. (2000) 'The political economy of war and peace in Afghanistan', World Development, 28(10), pp. 1789-1803.

Rubin, B. R. (2013) Afghanistan in the Post-Cold War Era. Oxford: OUP USA.

Sabates-Wheeler, R. and Verwimp, P. (2014) 'Extortion with protection: Understanding the effect of rebel taxation on civilian welfare in Burundi', The Journal of Conflict Resolution, 58(8), pp. 1474-1499.

Samatar, A. I. (2007) 'Ethiopian invasion of Somalia, US Warlordism \& AU Shame', Review of African Political Economy, 34(111), pp. 155-165.

Samatar, A. I. (2008) 'Somalia's post-conflict economy: A political economy approach', Bildhaan: An International Journal of Somali Studies, 7(1). Available at: https://digitalcommons.macalester.edu/ bildhaan/vol7/iss1/8. 
Samatar, A. I. (2016) Africa's First Democrats: Somalia's Aden A. Osman and Abdirazak H. Hussein. Bloomington: Indiana University Press.

Scheele, J. (2012) Smugglers and Saints of the Sahara: Regional Connectivity in the Twentieth Century. Cambridge: Cambridge University Press.

Shaw, S. (2013) 'Fallout in the Sahel: The geographic spread of conflict from Libya to Mali', Canadian Foreign Policy Journal, 19(2), pp. 199-210.

Shearer, D. (2000) 'Aiding or abetting? Humanitarian aid and its economic role in Civil War', in Berdal M. and Malone D. M. (eds) Greed and Grievance: Economic Agendas in Civil War. Lynne Rienner/IDRC.

Shelley, L. (2014) 'Blood money: How ISIS makes bank', Foreign Affairs. Available at: https:// www.foreignaffairs.com/articles/iraq/2014-11-30/blood-money (Accessed: 13 February 2016).

Shelley, L. I. (2014) Dirty Entanglements: Corruption, Crime, and Terrorism. New York, NY: Cambridge University Press.

Storholt (2001) 'Lessons learned from the 1990-1997 peace process in the North of Mali', International Negotiation, 6(3), pp. 331-356.

Thompson, V. B. (2015) Conflict in the Horn of Africa: The Kenya-Somalia border problem 1941-2014. Lanham: University Press of America.

Tucker, R. P. (1983) 'The British colonial system and the forests of the western Himalayas, 1815-1914', in Global Deforestation in the Nineteenth Century World Economy. Durham, NC: Duke University Press.

Weinstein J. M. (2007) Inside Rebellion: The Politics of Insurgent Violence. New York: Cambridge University Press.

Welch, D. A. (1993) Justice and the Genesis of War. Cambridge England; New York, NY: Cambridge University Press. 